\title{
PROBLEMATYKA PARTII POLITYCZNYCH W ORZECZNICTWIE TRYBUNAŁU KONSTYTUCYJNEGO
}

DOI: http://dx.doi.org/10.12775/TSP-W.2016.002

Summary. The issue of political parties in the judicial practice of the Constitutional Tribunal. When considering the issue of political parties in the judicial practice of the Constitutional Tribunal it should be noted that it passes judgements in two contexts. The first is related to constitutionality of the purposes or activities of political parties, the second appears in the context of deciding on the issues that are not strictly related to political parties. The reference point is what distinguishes them both. The decision-making activity of the Tribunal does not extend far in either of the scopes. Selected rulings will be discussed in the order of chronology and the importance of given issues.

Keywords: political parties; the issue of political parties in the judicial practice of the Constitutional Tribunal; Constitutional Tribunal; activities of political parties.

Riassunto. I partiti politici nella giurisprudenza costituzionale in Polonia. Il presente studio sui partiti politici nella giurisprudenza del Tribunale Costituzionale è volto a mettere in luce le linee essenziali dell'orientamento del giudice costituzionale polacco sull'argomento. Vengono analizzate le pronuncie in materia emesse dopo l'entrata in vigore della Costituzione polacca nel 1997 che non sono numerose. Il Tribunale polacco si pronuncia sui partiti politici in due contesti: 1) quando decide della conformità alla Costituzione dei fini e delle attività dei partiti politici; 2) quando affronta questioni che non sono necessariamente legate alla problematica dei partiti. Diverso è quindi un punto di riferimento. Lo studio non affronta il tema della legge sul funzionamento dei 
partiti politici. Sono inoltre esclusi dall'analisi questioni legate alla legge elettorale e alla partecipazione dei partiti politici alle elezioni.

Parola chiave: partiti politici; partiti politici nella giurisprudenza costituzionale in Polonia; Tribunale Costituzionale; attività dei partiti politici; legge elettorale.

I. Rozpoczynając rozważania dotyczące problematyki partii politycznych w orzecznictwie Trybunału Konstytucyjnego należy zauważyć, że organ ten orzeka niejako w dwóch kontekstach. Pierwszy z nich związany jest z konstytucyjnością celów lub działalności partii politycznych, drugi zaś pojawia się na tle rozstrzygania przez TK innych kwestii, które nie są związane wyłącznie z partiami politycznymi. Różny jest zatem punkt odniesienia. Działalność orzecznicza Trybunału nie jest szeroka zarówno w pierwszym, jak i w drugim zakresie ${ }^{1}$. Niemniej jednak w czynionych tutaj uwagach przyjęto założenie, zgodnie z którym analizie poddane zostaną orzeczenia TK wydane po wejściu w życie Konstytucji RP z 1997 r. Przedmiotem dociekań nie będzie także aktualny stan prawny w zakresie funkcjonowania partii politycznych. Wyłączono również z analizy kwestie związane z prawem wyborczym oraz uczestnictwem partii w wyborach. Wybrane judykaty zostaną omówione w kolejności chronologiczno-problemowej.

W odniesieniu do pierwszego z wyróżnionych kontekstów należy wskazać, że cztery postępowania toczące się przed TK zostały umorzone. Jedno dotyczyło badania statutu partii (Pp 1/02, umorzenie z powodu cofnięcia wniosku). Drugie postępowanie odnosiło się do konstytucyjności działalności partii politycznej i zakończone zostało umorzeniem z powodu dyskontynuacji prac parlamentu (Pp 1/07). Niedopuszczalność wydania wyroku była przyczyną umorzenia postępowania w przypadku postanowienia z 24 listopada 2010 r. (Pp 1/08) oraz postanowienia z 6 kwietnia 2011 r. (Pp 1/10). Różne były natomiast podstawy takiego rozstrzygnięcia. W pierwszym przypadku Trybunał uznał, że charakter podejmowanych działań przez partię nie uzasadniał jej delegalizacji w trybie kontroli represyjnej. W drugim zaś głównym powodem były braki formalne wniosku. Jedyny zaś wyrok Trybunału dotyczył zgodności z Konstytucją statutu partii politycznej w sprawie Pp 1/99.

W odniesieniu do drugiej sfery orzekania TK zajął się możliwością wystąpienia ze skargą konstytucyjną przez partię polityczną, ograniczeniami w zakresie przynależności do partii politycznej, monopolu partii politycznej w zakresie

${ }^{1}$ Orzeczenia Trybunały zostały częściowo przedstawione i skomentowane w doktrynie, np. J. Uliasz, Władza sadownicza wobec partii politycznych w Polsce - zagadnienia wybrane, „Przegląd Prawa Konstytucyjnego” 2011, nr 2, s. 99-110. 
wpływania metodami demokratycznymi na kształtowanie polityki państwa oraz finansowaniem ugrupowań politycznych.

Niezależnie zaś od sfery orzekania przewija się kwestia statusu prawnego i roli partii politycznych w państwie demokratycznym ${ }^{2}$.

II. W pierwszej kolejności przeanalizować wypada judykaty dotyczące konstytucyjności celów lub działalności partii politycznej. Istotą postępowania w tym przypadku jest ustalenie, czy cele lub działalność partii są zgodne z Konstytucją. Stąd też procedury w tym zakresie kojarzone są z nadzorem nad partiami ${ }^{3}$. Trybunał uwzględniać powinien wszystkie normy konstytucyjne, choć głównym wzorcem kontroli będzie art. 11 ust. 1 oraz art. 13 Konstytucji RP z 1997 r.

W wyroku z 8 marca 2000 r. (Pp 1/99) TK dokonał kilku ważnych ustaleń. Przede wszystkim odniósł się do legitymacji wnioskowej Sądu Okręgowego w Warszawie. Konstytucja w art. 191 określa podmioty uprawnione do wszczęcia postępowania przed TK. Niemniej jednak ustrojodawca zróżnicował legitymację procesową tych podmiotów. Zgodnie z ustaleniami doktryny wyróżnione zostały w trybie procedury abstrakcyjnej podmioty legitymowane ogólnie (generalnie) i funkcjonalnie ${ }^{4}$. Wśród nich nie ma sądu rejestrującego partie polityczne. Obok hierarchicznej kontroli norm (art. 188 pkt 1-3 i 5 Konstytucji RP), Trybunał orzeka także o zgodności z konstytucją celów lub działalności partii politycznych (art. 188 pkt 4). Konstytucja nie określa jednak formy, w jakiej cele te powinny być wyrażone, aby mogły stać się przedmiotem kontroli. Nie czyni tego art. 11 ustawy zasadniczej, określający pozycję ustrojową partii, ani art. 58 dotyczący wolności zrzeszania się i zakresu ograniczeń tej wolności. Zdaniem Trybunału pojęcie ,programu” w rozumieniu art. 13 Konstytucji RP ma charakter najbardziej ogólny i obejmuje wszelkie formy wyrażania sprzecznej z konstytucją treści. Konstytucja tworzy więc materialnoprawną podstawę kontroli zgodności z konstytucją celów lub działalności partii politycznych, jednakże tryb tej kontroli konkretyzuje ustawa o partiach politycznych z $1997 \mathrm{r}^{5}$

2 Tematyka ta została szeroko omówiona w doktrynie w aspekcie już teraz historycznym, np. M. Chmaj, M. Żmigrodzki, Status prawny partii politycznych w Polsce, Toruń 1995, a także uwzględniającym aktualny stan prawny i konstytucyjny oraz aspekt porównawczy, np. A. Domańska, K. Skotnicki (red.), Prawne aspekty funkcjonowania partii politycznych w państwach Europy Środkowej $i$ Wschodniej, Łódź 2003; J. Sułkowski, Pozycja ustrojowo prawna partii politycznych w Polsce, Czechach, na Stowacji i na Wegrzech, Łódź 2010.

${ }^{3}$ Szerzej na ten temat por. M. Bartoszewicz, Nadzór nad partiami politycznymi w polskim porządku konstytucyjnym, Warszawa 2006.

${ }^{4}$ Por. A. Kustra, Trybunat Konstytucyjny, w: Prawo konstytucyjne, Z. Witkowski, A. Bień-Kacała (red.), Toruń 2015, s. 499-500.

${ }^{5}$ Zob. aktualnie obowiązująca ustawa o partiach politycznych z dnia 27 czerwca $1997 \mathrm{r}$. (tj. Dz.U. z 2011 Nr 155, poz. 924). 
W świetle wskazanej ustawy dokumentem, w którym partia określa cele, strukturę i zasady działania, jest statut, uchwalany przez zgromadzenie ogólne członków partii lub zgromadzenie ich demokratycznie wybranych przedstawicieli (art. 10). Ten dokument, jako podstawa programowo-organizacyjna partii, jest warunkiem wpisu do ewidencji i przedmiotem badania w toku sądowego postępowania co do zgodności celów z konstytucją. Trybunał zauważył jednocześnie, że przedmiotem postępowania w sprawie o zbadanie zgodności celów lub działalności partii politycznych z konstytucją jest statut, czyli akt nienormatywny. Nie można więc przyjąć, że podmiotom legitymowanym do wszczęcia postępowania o zbadanie hierarchicznej zgodności norm, przysługuje prawo inicjowania kontroli zgodności aktów nienormatywnych. Ze względu na tak ustalony przedmiot kontroli TK uznał również, że przewidziana w art. 193 Konstytucji RP kontrola konkretna (pytanie prawne) nie rozciąga się na te przypadki. Można jedynie dostrzec w tym przypadku daleko idące podobieństwa do wystąpień Sądu Okręgowego w Warszawie (sądu rejestrowego) w trybie art. 14 i 21 ustawy o partiach politycznych.

Zdaniem TK, pomimo braku wyraźnej normy konstytucyjnej, odmienność trybu postępowania i przedmiotu kontroli pozwala na przyjęcie wykładni w zgodzie z konstytucją i w konsekwencji uznanie dopuszczalności wystąpienia do TK przez SO w Warszawie o zbadanie konstytucyjności statutu lub działalności partii politycznej.

Drugim istotnym problemem omówionym przez TK jest pozycja ustrojowa i charakter prawny partii. Trybunał zauważył, że partia polityczna jest z jednej strony formą urzeczywistniania wolności zrzeszania się obywateli polskich, z drugiej strony stanowi ona ważny element systemu politycznego, ze względu na jej zdolność oddziaływania na kształtowanie polityki państwa,.

W odniesieniu do wolności zrzeszania się TK zauważył, że ogólne jej określenie oraz granice zawarte są w art. 58 i art. 31 ust. 3 Konstytucji RP. Przepisy te niewątpliwie dotyczą także partii politycznych, niemniej jednak wymagają pewnych modyfikacji wynikających $\mathrm{z}$ art. 11 ust. 1 i art. 13 ustawy zasadniczej (wolność ta dotyczy wyłącznie obywateli polskich; wymaga dobrowolności i równości; celem partii ma być wpływanie metodami demokratycznymi na kształtowanie polityki państwa; ograniczenia w korzystaniu z tej wolności mogą wynikać jedynie wprost z postanowień konstytucji; ich źródłem nie mogą być ustawy). Modyfikacja ta związana jest z traktowaniem partii jako ważnego i konstytucyjnie niezbędnego elementu liberalnego demokratycznego porządku prawnego. Główną ich funkcją jest wpływanie na kształtowanie polityki państwa, co gwarantowane jest przez odpowiednie regulacje konstytucyjne i ustawowe. Status prawny partii wyznaczany jest przede wszystkim przez art. $11 \mathrm{i}$ art. 13 Konstytucji RP. Miejsce tych przepisów oraz ich treść świadczą o nadaniu par- 
tiom rangi „podstawowej instytucji publicznego życia politycznego" ${ }^{\text {. Zgodnie }}$ ze stanowiskiem Trybunału zasada pluralizmu politycznego (art. 11) uważana jest za nienaruszalną zasadę ustrojową ze względu na znaczenie i funkcje partii w państwie demokratycznym. Jej treść wyznaczana jest przez inne podstawowe zasady ustroju RP, w szczególności demokratycznego państwa prawnego (art. 2), zwierzchnictwa narodu (art. 4) i legalności (art. 7). Konstytucja wprowadza także zasadę jawności finansowania partii politycznych (art. 11 ust. 2). Obowiązek jawności dotyczy także struktur lub członkostwa (a contrario z art. 13).

Trzecia kwestia, którą zajął się TK dotyczy ingerencji ze strony władzy publicznej w wewnętrzna strukturę partii politycznej. Trybunał odwołał się przy tym do przedkonstytucyjnej uchwały z 24 kwietnia 1996 r. (W 14/95) i uznał, że konstytucyjne prawo zrzeszania się obywateli w partie polityczne nie wyklucza możliwości ustanowienia przez ustawodawcę jego granic czy też procedur prawnych korzystania z niego. Wolności obywateli nie mają bowiem charakteru absolutnego i mogą podlegać ograniczeniom. Granice te mogą być ustanawiane zarówno w interesie samych partii, jak też w interesie publicznym, w celu gwarantowania demokratycznego ustroju państwa. W związku z tym Trybunał sformułował wniosek w zakresie wewnętrznej organizacji partii politycznej. Powinna ona posiadać odpowiednią strukturę, która zapewniać ma możliwość sprawnego funkcjonowania. Wymaga to ujęcia w odpowiednim dokumencie pełniącym rolę statutu partii. Owa organizacja wewnętrzna, a więc członkostwo i struktura partii mają być ponadto urządzone na zasadach równości i dobrowolności, a więc na zasadach demokratycznych. Złamanie jednej z wymienionych zasad organizacji, czy to w odniesieniu do członkostwa w partii (np. nierówny status prawny członków partii z powodu płci czy rasy), czy struktury wewnętrznej, nie pozwoliłoby odpowiedniemu organowi zaklasyfikować danej organizacji społecznej (politycznej) do grona partii politycznych.

Warunki te dotyczą nie tylko rozwiązań ustawowych, ale również wewnątrzorganizacyjnych dotyczących celu powołania partii, jej środków działania, ustroju władz czy też zagadnień związanych z członkostwem (statuty partyjne). Partia powinna więc $\mathrm{w}$ statucie lub innym dokumencie cel sytuować $\mathrm{w}$ obszarze wpływu na kształtowanie polityki państwa. Zarówno cel, jak i przyjęte środki działania powinny być demokratyczne. TK uznał w konsekwencji, iż postulat „demokratycznych metod” odnosi się nie tylko do działalności „zewnętrznej” partii, a więc głównie do sfery jej aktywności politycznej, ale również działalności ,wewnętrznej” odnoszącej się do jej struktury i zasad członkostwa.

6 TK odwołał się przy tym do kluczowego w orzecznictwie opracowania J. Majchrowskiego, Partie polityczne w świetle nowej Konstytucji, „Państwo i Prawo” 1997, nr 11-12, s. 169. 
Niemniej jednak w wyroku z 2000 r. Trybunał uznał, że niedemokratyczne elementy wewnątrzorganizacyjne nie zawsze muszą mieć bezpośredni i istotny wpływ na wypełnianie przez partię jej roli ustrojowej lub stosowane przez nią zewnętrzne metody działania. W związku z tym swoboda kształtowania wewnętrznych struktur i zasad funkcjonowania partii nie może być ograniczana, jak długo nie zagraża wypełnianiu przez partię jej konstytucyjnej roli lub jak długo nie wyklucza demokratyczności metod, jakimi partia zamierza wpływać lub wpływa na kształtowanie polityki państwa. Brak demokracji wewnątrzorganizacyjnej musi natomiast być brany pod uwage przy orzekaniu o zgodności z konstytucją celów lub działalności partii politycznych, jeżeli uniemożliwia lub choćby tylko w istotny sposób ogranicza spełnianie przez partię jej konstytucyjnej roli lub przekłada się bezpośrednio na zakładane lub stosowane przez nią metody kształtowania polityki państwa. Oznacza to konieczność dokonywania ocen odnoszonych zawsze do konkretnego przypadku, przy czym oceny te powinny obejmować całokształt założeń programowych, zasad statutowych i praktyk stosowanych przez daną partię polityczną. Jedynymi abstrakcyjnie i bezwzględnie określonymi w konstytucji ograniczeniami swobody kształtowania wewnętrznych struktur i zasad działania partii politycznych są zakazy zawarte w art. 13 Konstytucji RP. Zdaniem Trybunału ustrojodowca opowiedział się za koniecznością zachowania daleko idącej powściągliwości co do możliwości i zakresu ingerencji władz publicznych, w tym ustawodawcy, w wewnętrzne struktury czy zasady działania partii. Autonomia kształtowania wewnętrznych struktur jest bowiem pochodną wolności tworzenia partii. Ingerencja zewnętrzna może wchodzić w grę wtedy, gdy struktura taka w sposób jednoznaczny i oczywisty odbiega od standardów demokratycznego państwa prawnego i właściwego dla niego systemu wartości. W razie wątpliwości domniemanie przemawia za zgodnością z konstytucją.

Następnym w kolejności wydanym przez TK orzeczeniem było postanowienie z 16 lipca 2003 r. (Pp 1/02). Trybunał umorzył postępowanie na skutek cofnięcia wniosku, niemniej jednak dokonał pewnych interesujących ustaleń.

W odniesieniu do rodzajów postępowań przed Trybunałem doszło do usystematyzowania stanowiska wyrażonego wyroku z 8 marca 2000 r. (Pp 1/99). Trybunał zauważył bowiem, że prowadzona przez ten organ kontrola realizowana jest w dwóch formach: kontroli prewencyjnej, określanej też jako profilaktyczna, dotyczącej celów partii politycznej określonych w statucie lub programie i kontroli represyjnej, zwanej też następczą, która dotyczy działalności partii politycznej.

Z pierwszą postacią kontroli (prewencyjną) mamy do czynienia w procesie powstawania partii, na etapie rozpatrywania przez Sąd Okręgowy w Warszawie wniosku o wpis do ewidencji partii politycznych (art. 14 ustawy o partiach poli- 
tycznych), a także w przypadku zgłoszenia do sądu wniosku o wpis do ewidencji zmian wprowadzonych w statucie (art. 21 ustawy o partiach politycznych). Inicjatorem kontroli jest $\mathrm{w}$ obu przypadkach sąd prowadzący ewidencję partii politycznych. Postępowanie przed TK ma charakter wpadkowy; stanowi pewien incydent w toku właściwego postępowania (o wpis do ewidencji), toczącego się przed sądem powszechnym; od jego wyniku zależą losy postępowania właściwego. Jednocześnie kontrola prewencyjna ma charakter abstrakcyjny i w istocie zbliża się do kontroli zgodności aktów normatywnych z Konstytucją. Zadaniem Trybunału jest dokonanie wykładni statutu, programu i innych dokumentów, na których ma się opierać działalność partii, odtworzenie na tej podstawie jej celów lub zasad działania oraz skonfrontowanie ich ze standardami konstytucyjnymi. Z samej natury kontroli prewencyjnej wynika, że nie może ona prowadzić do delegalizacji partii; jej celem jest jedynie zapobieżenie wpisowi do ewidencji partii, które nie odpowiadają określonym kryteriom prawnym, ewentualnie zapobieżenie wprowadzeniu do statutu partii zmian, które tych warunków nie spełniają.

Z kontrolą represyjną mamy do czynienia, gdy zachodzą wątpliwości, czy działalność partii już wpisanej do ewidencji jest zgodna z Konstytucją. W takim przypadku sąd nie jest już upoważniony do inicjowania kontroli przed TK. Wyrazem nadzoru nad działalnością partii jest natomiast dopuszczenie wniosku pochodzącego od podmiotów wskazanych w art. 191 ust. 1 pkt 1 Konstytucji. Każdy z nich może zainicjować kontrolę, jeśli poweźmie wątpliwości co do konstytucyjności poczynań partii. W tym przypadku zadaniem Trybunału jest przeprowadzenie postępowania dowodowego w celu ustalenia, czy działalność partii narusza zasady konstytucyjne. Nadzór represyjny może prowadzić do delegalizacji partii przez TK i do jej wykreślenia z ewidencji partii politycznych.

W kontekście rodzajów postępowań Trybunał zauważył, iż warunkiem koniecznym wejścia w życie nowego statutu jest ujawnienie jego postanowień w ewidencji. Do czasu dokonania stosownego wpisu partia powinna opierać swą działalność na statucie w pierwotnym kształcie, którego konstytucyjność nie została zakwestionowana. Partia, która poprzestaje na wpisie do ewidencji „fasadowego", choć niesprzecznego z Konstytucją statutu, w rzeczywistości opierając swą działalność na innej, niekonstytucyjnej regulacji, musi się liczyć z zastosowaniem wobec niej kontroli represyjnej, która koncentruje się na ocenie rzeczywistej działalności.

Następne postanowienie zapadło 17 grudnia 2007 r. (Pp 1/07). Trybunał umorzył postępowanie ze względu na niedopuszczalność wydania wyroku. Sprawa dotyczyła problemu uzależniania możliwości kandydowania z ramienia Samoobrony RP od uprzedniego podpisania stosownej umowy zabezpieczonej wekslem (pomiędzy partią a kandydatem). Trybunał zauważył, że podjęte dzia- 
łania związane z podpisywaniem umów i weksli mogą stanowić potencjalne naruszenie art. 11 ust. 1 i 2 oraz art. 104 ust. 1 Konstytucji. Niemniej jednak nie doszło do merytorycznego zbadania sprawy z uwagi na koniec kadencji Sejmu. Trybunał wskazał, że zakończenie kadencji tego organu skutkuje wygaśnięciem, płynących ze sprawowania mandatu, indywidualnych i zbiorowych praw posłów oraz praw wszystkich organów Sejmu. Dotyczy to również Marszałka Sejmu jako wnioskodawcy w sprawie przed TK.

Postanowieniem z 24 listopada 2010 r. (Pp 1/08) Trybunał umorzył postępowanie również z uwagi na niedopuszczalność wydania wyroku. Wniosek w tej sprawie stanowił kontynuację postępowania omówionego wyżej, został natomiast złożony w Sejmie nowej kadencji. W obu przypadkach mieliśmy do czynienia $\mathrm{z}$ procedurą kontroli represyjnej. W analizowanym orzeczeniu Trybunał ustalił, że działalność partii politycznej, która może być przedmiotem kontroli, oznacza działania podejmowane w określonym celu przez partię jako szczególny rodzaj zrzeszenia. Mogą to być zarówno działania władz partii, jak i niższych jej struktur. Działalność ta odnosi się przede wszystkim do faktów i obejmuje zarówno działania partii w sferze wewnętrznej (np. w stosunku do członków partii czy organów partii), jak i zewnętrznej (np. w stosunku do osób niebędących członkami partii, innych zrzeszeń, organów państwa). Za działalność partii politycznej nie można natomiast uznać jednostkowych zachowań jej członków, które wykraczają poza ramy politycznego programu tej partii. Działalność ta nie obejmuje też zaniechania. Szczególnie pomocne dla określenia działalności danej partii mogą być działania jej władz i niższych struktur, jej statut, przyjmowane programy, wydawane polecenia, zawierane umowy.

W kontekście zasady pluralizmu politycznego i z uwagi na powiązanie jej z wolnością zrzeszania się należy jednak zachować ostrożność przy kwalifikacji konkretnych postaci działalności partii jako wymagających konstytucyjnej dezaprobaty. Ocena konstytucyjności działalności wymaga analizy faktów na podstawie zgromadzonego materiału dowodowego, nie tylko stwierdzenia ich istnienia, ale także natężenia zjawiska i jego skutków. Życie polityczne może kusić do sięgnięcia przed TK po ten środek kontroli konstytucyjności w ramach walki politycznej. Nieostre, zbyt liczne przesłanki sięgania do tego środka mogłyby zagrozić pluralizmowi politycznemu, będącemu jedną z podstaw ustrojowych RP. Stąd też relewantnym odniesieniem jest art. 13 Konstytucji RP. Przepis ten zawiera normę wykluczającą możliwość legalnego funkcjonowania określonych partii politycznych i innych organizacji. Zakaz istnienia partii jest równoznaczny z obowiązkiem sądu rejestrowego odmowy dokonania wpisu, jeżeli TK wyda orzeczenie o sprzeczności celów partii politycznej z Konstytucją, bądź z obowiązkiem niezwłocznego wykreślenia partii z ewidencji (i jej likwidacji), jeżeli 
Trybunał wyda orzeczenie o sprzeczności z Konstytucją celów lub działalności partii ${ }^{7}$.

Niemniej jednak każde zdelegalizowanie radykalnej partii politycznej jest skrajnym środkiem ingerencji państwa w zasadę pluralizmu politycznego. Środek ten powinien być stosowany w przypadku absolutnej konieczności. Należy przede wszystkim kierować się naczelną zasadą, że wolność tworzenia i działania partii jest jednym z filarów demokracji. Dlatego w każdym przypadku musi być to akt ultima ratio, po wykluczeniu innych czynności prawnych podejmowanych przez kompetentne organy państwa $\mathrm{w}$ reakcji na niezgodną $\mathrm{z}$ prawem działalność partii politycznej. Nie bez powodu wszystkie reżimy totalitarne lub skrajnie niedemokratyczne wprowadzają system monopartyjny lub zakazują istnienia partii politycznych.

W analizowanej sprawie Trybunał zauważył, że stosowane praktyki związane z wekslami ograniczają konstytucyjną dobrowolność członkostwa w partii. Wolność wystąpienia z niej lub z klubu parlamentarnego nie powinna być bowiem ograniczana przez jakiekolwiek czynności prawne. Niemniej jednak naganność takich praktyk jest mniejsza niż przyczyny decydujące o zakazie istnienia partii politycznych (art. 13 Konstytucji RP - szerzenie nienawiści rasowej, narodowościowej, wywrotowość wobec porządku konstytucyjnego, tajność działania). $\mathrm{Z}$ tej przyczyny delegalizacja partii byłaby kwalifikacją nieproporcjonalną. Podobna konkluzja dotyczyła wpływu omawianego niedozwolonego instrumentu prawnego (weksel) na realizację mandatu wolnego.

W kontekście mandatu wolnego Trybunał zauważył, że jego cechy nie przekreślają oczywistej zależności politycznej posłów (senatorów) od partii, do których należą. Regulacje konstytucyjne prowadzą do faktycznego uzależnienia kandydata na parlamentarzystę i parlamentarzysty od organu partii podejmującego personalne decyzje wyborcze. Zależność polityczna wpływa niewątpliwie na sposób wykonywania mandatu, tak by dostosować zachowania do oczekiwań partii i jej klubu․ Nie sprzeciwia się ona jednak per se istocie mandatu wolnego. Zasadzie tej nie sprzeciwia się również dyscyplina partyjna (klubowa), rozumiana jako podejmowanie przez władze klubu ustaleń programowych i środków ich realizacji, w szczególności w postaci zalecenia odpowiedniego głosowania przez członków klubu (koła) połączonego z możliwością nałożenia sankcji klubowych. Założeniem jest jednak, że parlamentarzysta może w dowolnym mo-

${ }^{7}$ Por. także M. Serowaniec, Likwidacja, podziat i łączenie partii politycznych w Polsce, ,Toruńskie studia polsko-włoskie/Studi polacco-italiani di Toruń” 2016, t. XII, s. 322-324, DOI: http:// dx.doi.org/10.12775/TSP-W.2016.020

${ }^{8}$ Szerzej na temat relacji między partiami politycznymi a Sejmem por. S. Bożyk, Partie polityczne a Sejm RP, Warszawa 2006. 
mencie zwolnić się z tego obowiązku przez wystąpienie z partii lub klubu (koła). Jednocześnie podporządkowanie się parlamentarzysty dyscyplinie klubowej w głosowaniach zapewnia przewidywalność ich wyników i umożliwia sprawne działanie parlamentu, co stanowi samoistną wartość konstytucyjną.

W podsumowaniu orzeczenia TK zauważył, że twórcy Konstytucji RP, mając świadomość roli partii politycznych w państwie demokratycznym, wolności tworzenia i ich działania, nadali rangę konstytucyjnej zasady prawa. Zasada ta ma fundamentalny charakter dla realizacji pluralizmu politycznego, który jest jedną z gwarancji ustrojowych. Jedyny wyjątek od wolności tworzenia i działania partii zawiera art. 13 Konstytucji RP, w którym ustrojodawca, mając na uwadze doświadczenia dwudziestowiecznych totalitaryzmów, przewidział zakaz istnienia określonych partii politycznych i innych organizacji. W konsekwencji Trybunał przyjął, że delegalizacja partii w związku z jej działalnością, jako najsurowsza $\mathrm{z}$ form ingerencji państwa $\mathrm{w}$ zasadę pluralizmu politycznego, jest możliwa tylko w przypadkach, gdy podstawą rozstrzygnięcia będzie art. 13 Konstytucji RP.

Postanowieniem z 6 kwietnia 2011 r. (Pp 1/10) TK umorzył postępowanie ze względu na niedopuszczalność wydania wyroku. Postępowanie to zostało wszczęte w trybie kontroli prewencyjnej przed wpisaniem do ewidencji symboli graficznych partii politycznej. W pierwszej kolejności Trybunał musiał ustalić, czy znaki graficzne mogą być przedmiotem kontroli konstytucyjności celów i zasad działania partii politycznej.

Trybunał wskazał, że program partii Narodowe Odrodzenie Polski nie został jasno i jednoznacznie wyłożony w jej statucie. Program wprost nie odwołuje się do totalitarnych metod, nie wyraża nienawiści rasowej czy narodowościowej, a zatem kategorii wpisanych do art. 13 Konstytucji RP. Wątpliwości konstytucyjne sądu wiążą się wyłącznie z symbolami, które chce zarejestrować partia. Ustawa zasadnicza nie określa formy, w jakiej cele oraz zasady działania partii powinny być wyrażone, aby mogły stać się przedmiotem kontroli ich zgodności z Konstytucją. Pojęcie „programu” w rozumieniu art. 13 Konstytucji ma charakter najbardziej ogólny, obejmujący wszelkie formy wyrażania treści relewantnej z perspektywy oceny jej zgodności z ustawą zasadniczą (Pp 1/99). Cele partii politycznej należy oceniać zatem przez pryzmat celów określonych w statucie lub w programie (W 15/92). Także nowe symbole, które partia zamierza wpisać do rejestru, są relewantne z perspektywy celów lub zasad działania partii. Ocenie Trybunału podlegają więc treści, jakie wyrażają te znaki. Treści płynące zarówno ze statutu, jak i z programu oraz innych dokumentów, w tym również z symboli graficznych partii politycznej, określają jej tożsamość ideową. Symbol graficzny partii jest bowiem formą ekspresji poglądów.

Przedmiotem kontrowersji w omawianej sprawie nie była jednak merytoryczna ocena znaków graficznych i zakodowanych w nich treści, tylko kwestie procedural- 
ne. Przede wszystkim TK stwierdził poprawność wystąpienia przez SO w Warszawie z wnioskiem o zbadanie konstytucyjności celów lub zasad działania partii politycznej w kontekście zgłoszonych do rejestracji symboli graficznych. W odniesieniu natomiast do wymogów formalnych pisma inicjującego postępowanie Trybunał stwierdził, że badany wniosek nie spełnia wymogów formalnych. Przede wszystkim problem dotyczy braku należytego uzasadnienia zarzutów, pomimo wezwania do uzupełnienia braków w tym względzie.

Należy jednak zaznaczyć, że nie była to kwestia oczywista, gdyż do postanowienia złożono 5 zdań odrębnych. Dodatkowo Trybunał wskazał, że istnieje możliwość ponownego wdrożenia postępowania w sytuacji prawidłowo złożonego i uzasadnionego wniosku.

W tej sprawie sąd zarejestrował znaki, niemniej jednak z uwagi na złożenie apelacji przez RPO sąd apelacyjny ostatecznie uchylił postanowienie o rejestracji znaków9 .

III. Problemy szczegółowe, które pojawiły się w orzecznictwie TK zostaną zaprezentowane według założeń wskazanych na wstępie. W odniesieniu do prawa występowania ze skargą konstytucyjną należy wskazać postanowienie z 17 listopada 2010 r. (Ts 256/09). Trybunał odmówił nadania dalszego biegu skardze konstytucyjnej wniesionej przez PSL z powodu braku legitymacji do wniesienia skargi. Brak legitymacji partii związany jest przede wszystkim z funkcją, którą spełnia skarga konstytucyjna będąca środkiem ochrony konstytucyjnych wolności lub praw. Funkcja ta nie jest do pogodzenia z charakterem partii jako podmiotu o charakterze publicznoprawnym, uczestniczącym w sprawowaniu władzy publicznej. Wolności lub prawa konstytucyjne mają bowiem na celu ochronę jednostki. Określają one relacje jednostki wobec państwa oraz innych podmiotów władzy publicznej. Organy władzy publicznej obowiązane są do zapewnienia realizacji wolności i praw oraz korzystania z nich. Podmiotem uprawnionym jest jednostka, a podmiotem zobowiązanym władza publiczna. Podmioty wpływające przez swoją działalność na organy władzy publicznej oraz kształt ustrojowy państwa nie posiadają zdolności skargowej. Dotyczy to zwłaszcza partii politycznych, a także ich funkcjonowania w sferze prawa publicznego. Partie nie są bowiem zwykłymi beneficjentami poszczególnych praw lub wolności konstytucyjnych. Status prawny partii jest przecież wyraźnie uregulowany poza przepisami o wolnościach i prawach człowieka i obywatela. Ponadto z istoty rzeczy partie korzystają ze swych praw w celu wpływania na realizację zadań publicznych przez państwo. Jednocześnie jednak Trybunał zaznaczył, że jest możliwa ochrona praw konstytucyjnych partii politycznych w sferze, w któ-

${ }^{9}$ Zob. https://www.rpo.gov.pl/en/node/1211 (dostęp 3.06.2016). 
rej występują one jako podmioty prawa prywatnego, na podstawie przepisów powszechnego prawa prywatnego, a nie jako podmioty wykonujące zadania wynikające $\mathrm{z}$ art. 11 Konstytucji RP. Z taką sytuacją potencjalnie moglibyśmy mieć do czynienia, gdyby partia będąca właścicielem nieruchomości kwestionowała zgodność z Konstytucją unormowań prawa rzeczowego, na podstawie których zostało wydane ostateczne orzeczenie naruszające jej prawo własności. Mamy zatem do czynienia niejako z dwoistym obliczem partii politycznych.

Zakaz przynależności do partii politycznej funkcjonariuszy państwowych oraz osób zajmujących określone stanowiska publiczne stał się przedmiotem wyroku z 10 kwietnia 2002 r. (K 26/00). Trybunał uznał konstytucyjność rozwiązań ustawowych w odniesieniu m.in. do: żołnierzy zawodowych, prokuratorów, funkcjonariuszy Policji, Straży Granicznej czy też osób zatrudnionych w NIK. Jak zauważył organ orzekający, ustrojodawca zakazuje pewnym kategoriom osób przynależności do partii politycznych oraz związków zawodowych. Należą do nich choćby sędziowie czy też RPO. Konstytucyjnego uregulowania zakazu członkostwa w partiach nie można jednak traktować jako katalogu zamkniętego.

Wolność zrzeszania się $\mathrm{w}$ partie polityczne nie stanowi ponadto, zdaniem TK, wartości autonomicznej, lecz związana jest ściśle z rolą, jaką Konstytucja przypisuje partiom w strukturze państwa. Prawo do członkostwa w partiach politycznych postrzegać należy zatem nie w kategoriach wolności zrzeszania, lecz w kategoriach prawa do wpływania metodami demokratycznymi na kształtowanie polityki państwa. Wolność zrzeszania się jako prawo podmiotowe jednostki sformułowana została w art. 58 Konstytucji RP. Istotą jej jest możliwość tworzenia przez obywateli sformalizowanych więzi organizacyjnych o celach i zadaniach nie reglamentowanych przez państwo. Wolność ta stanowi o możliwości funkcjonowania społeczeństwa obywatelskiego. Naruszeniem istoty tego prawa w stosunku do określonej kategorii osób byłoby wprowadzenie zakazu zrzeszania się tych osób w jakiejkolwiek organizacji i w ten sposób sytuowanie ich jako zbiorowości jednostek wyłączonej ze struktur społeczeństwa obywatelskiego. Szczególna natomiast rola partii politycznych w życiu publicznym powoduje, iż za uzasadnione należy uznać ograniczenie wolności zrzeszania się tam, gdzie może zachodzić kolizja pomiędzy funkcją jaką spełniają partie polityczne a kompetencjami przypisanymi osobom wykonującym władzę publiczną. Większość z zakwestionowanych przepisów dotyczy sytuacji prawnej funkcjonariuszy szeroko pojętej służby publicznej.

W wyroku z 27 maja 2003 r. (K 11/03) Trybunał odniósł się między innymi do kwestii monopolu partii politycznych na wpływanie metodami demokratycznymi na politykę państwa. Taka koncepcja, zdaniem TK, nie ma uzasadnienia w konstytucyjnym porządku prawnym RP. Konstytucja tworzy przesłanki dla 
funkcjonowania społeczeństwa obywatelskiego, w którym właśnie obywatele, zorganizowani w różnych strukturach formalnych (partie polityczne, stowarzyszenia, organizacje społeczne, fundacje) realizują swoje cele wpływając na sprawy publiczne. System demokratyczny tym m.in. różni się od totalitarnego, że wyklucza monopol partii na wpływanie na politykę państwa. Partie polityczne mają wprawdzie szczególny status, ale są jednym z wielu elementów struktury życia publicznego. Nie są ani elementem jedynym, ani nie mają monopolu, nie mogą ponadto ograniczać działalności innych struktur życia publicznego.

W wyroku z 14 grudnia 2004 r. (K 25/03) Trybunał odniósł się do pozycji ustrojowej partii politycznych i zauważył, że sam fakt umieszczenia przepisów o partiach politycznych w rozdziale I Konstytucji zatytułowanym „Rzeczpospolita” świadczy o randze, jaką ustrojodawca nadaje partiom politycznym ${ }^{10}$. Wyjątkowość ich roli polega na tym, że są one nie tylko jedną z form obywatelskiego prawa do zrzeszania się, ale przede wszystkim formą organizacji politycznej, która wywiera wpływ na sprawowanie władzy. Państwo akceptuje zasadniczą funkcję partii w systemie demokratycznym i uznaje ich prawo do wpływania na kształtowanie polityki państwa. Jest to funkcja publiczna, ściśle związana z władzą państwową. Partie stanowią element systemu politycznego i kojarzone są z podstawową instytucją publicznego życia politycznego.

Analizowany wyrok ma istotne znaczenie przede wszystkim w zakresie reguł finansowania partii politycznych ${ }^{11}$. Jak zauważył TK, na podstawie art. 11 Konstytucji RP partia polityczna jest dobrowolnym i opartym na zasadzie równości zrzeszeniem obywateli polskich w celu wpływania metodami demokratycznymi na kształtowanie polityki państwa. Nie są to zatem zrzeszenia powołane do prowadzenia działalności gospodarczej. Zapewnienie wolności tworzenia i działania partii politycznych nie ma nic wspólnego z proklamowaniem ich wolności gospodarczej, wyraża natomiast ustrojową gwarancję pluralizmu politycznego.

W kontekście art. 22 Konstytucji RP, który statuuje wolność działalności gospodarczej Trybunał zauważył, że konstytucyjna gwarancja wolności działalności gospodarczej nie jest adresowana do podmiotów prawa publicznego, które dysponują szczególnymi środkami wywierania wpływu na gospodarkę. Skoro ich zadaniem jest wpływanie na kształt polityki państwa mogą one również kształ-

${ }^{10}$ Szerzej na ten temat A. Bień-Kacała: Finansowanie kampanii wyborczej partii politycznej ze środków pochodzących z działalności gospodarczej, w: „Przemiany prawa wyborczego - doświadczenia nowych demokracji” Republika Czeska, Republika Słowacka, Republika Ukraińska, Rzeczpospolita Polska, red. A. Sokala, Z. Witkowski, Bydgoszcz 2007, s. 130-143, zob. także glosy do wyroku M. Granat oraz J. Sułkowski, „Przegląd Sejmowy” 2006, nr 1, s. 119-133.

${ }^{11}$ Szerzej o finansowaniu partii politycznych M. Bidziński, Finansowanie partii politycznych w Polsce, Warszawa 2011. 
tować normy prawne generalne regulujące funkcjonowanie gospodarki, a także brać udział w udzielaniu pozwoleń i koncesji, rozstrzyganiu przetargów itd.

Trybunał dodał także, że całkowite wyłączenie aktywności gospodarczej nastąpiło wraz z przyjęciem systemu finansowania partii z budżetu państwa. Zdecydował o tym ustawodawca wprowadzając model publicznego finansowania partii politycznych.

Do uzasadnienia tego wyroku zostało zgłoszone zdanie odrębne, które jest istotne $\mathrm{z}$ uwagi na podkreślenie odmiennego spojrzenia na pozycję partii politycznej. Zgodnie $\mathrm{z}$ nim partie nie powinny być postrzegane $\mathrm{w}$ sposób zbliżony do instytucji publiczno-prawnych, w tym zwłaszcza samorządu terytorialnego. $\mathrm{Z}$ takiego etatystycznego stanowiska, zrównującego instytucje socjologiczno-polityczną z instytucją publiczną, wypływa przekonanie, iż partie są niejako z góry skazane na najdalej idące ograniczenia praw majątkowych oraz wolności prowadzenia działalności gospodarczej. Konstytucja umożliwia wprawdzie bardzo daleko idące ograniczenia samodzielności majątkowej i finansowej partii, lecz nie takie, które w ogóle podważają sens nadania jej osobowości prawnej.

Kwestiom finansowania partii z budżetu państwa poświęcony został także wyrok z 20 stycznia $2010 \mathrm{r}$. (Kp 6/09) ${ }^{12}$. W zakresie roli i statusu partii politycznych w porządku konstytucyjnym Trybunał przypomniał swoje dotychczasowe orzecznictwo ${ }^{13}$. Kwestie te nie będą już analizowane w tym miejscu.

W odniesieniu do zasady jawności finansowania partii TK wskazał, że został jej przyznany charakter konstytucyjny (art. 11 ust. 2 Konstytucji RP). Znaczenie jawności finansowania partii podkreślał wielokrotnie w swym orzecznictwie zarówno TK, jak i SN ${ }^{14}$. Niewątpliwie stanowi ona istotne narzędzie społecznej kontroli funkcjonowania partii politycznych ${ }^{15}$. Przyjęty natomiast model finansowania partii z budżetu państwa nie wynika z norm konstytucyjnych, lecz ustawowych. Konstytucja nie rozstrzyga o sposobach finansowania, a wybór właściwego modelu pozostawia ustawodawcy. Ocena więc, który z możliwych wariantów zapewnienia finansowych podstaw działania partii jest najlepszy, nie należy do kompetencji TK.

${ }^{12}$ Szerzej na ten temat A. Bień-Kacała, Ograniczenie finansowania partii politycznych z budżetu państwa a równowaga budżetowa $w$ dobie kryzysu (uwagi na tle wyroku TK z 20 stycznia 2010, Kp 6/09), w: Normalność i kryzys. Jedność czy różnorodność, red. J. Oniszczuk, Warszawa 2010, s. 357-364 oraz J. Zbieranek (red.), Subwencje z budżetu państwa dla partii politycznych. Jawność i kontrola, Warszawa 2008.

13 Zob. wyroki z: 8 marca 2000 r., Pp 1/99 oraz 10 kwietnia 2002 r., K 26/00.

${ }^{14}$ Zob. wyroki z: 27 maja 2003 r., K 11/03; 13 lipca 2004 r., P 20/03; 14 grudnia 2004 r., K 25/03 oraz postanowienie składu 7 sędziów SN z 1 października 2003 r., III SW 152/03, OSNP nr 10/2004, poz. 181.

15 Zob. wyrok TK z 14 grudnia 2004 r., K 25/03. 
Trybunał posiłkując się zdaniem doktryny wskazał zalety i wady modelu finansowania partii ze środków publicznych ${ }^{16}$. Jako zalety wymienia się: wyrównywanie szans poszczególnych ugrupowań w systemie partyjnym, zapobieganie przekształcaniu się partii w organizacje nastawione na zysk, ochronę partii przed grupami nacisku i niebezpieczeństwem korupcji, tworzenie gwarancji dla stałej działalności polityczno-organizacyjnej oraz sprzyjanie stabilizacji systemu partyjnego. Z kolei krytycy subwencjonowania partii z budżetu wskazują, że można w ten sposób doprowadzić do zagrożenia demokratycznych procedur gry politycznej, a w szczególności do osłabienia opozycji w systemie politycznym, umożliwienia organom państwowym nadmiernej ingerencji w wewnętrzne sprawy partii oraz wzmacniania procesów etatyzacji partii, a także wzmacniania status quo w systemie partyjnym.

Kluczowym problemem w analizowanym wyroku była kwestia ograniczenia kwoty subwencji należnych partiom politycznym lub koalicjom wyborczym. Trybunał zauważył, że pilna potrzeba zachowania równowagi budżetowej w warunkach wysoce niekorzystnego stanu finansów publicznych spowodowała, iż sprawą priorytetową było dochowanie wartości konstytucyjnej w postaci równowagi budżetowej. Stąd też zagrożenie dla jej zachowania uzasadniało dokonywanie ograniczeń wydatków budżetowych, w tym zmniejszenie subwencji przysługujących z budżetu państwa i związane z tym ograniczenie praw nabytych partii politycznych.

W tym też kontekście TK stwierdził, że obniżenie wysokości subwencji na działalność statutową nie narusza zasady pluralizmu politycznego, a wręcz sprzyja jej, z uwagi na to, że większa redukcja środków publicznych została dokonana w stosunku do partii otrzymujących subwencje w najwyższej wysokości. W wyniku zmian dokonanych w zaskarżonej ustawie różnice pomiędzy finansowaniem poszczególnych partii ze środków publicznych miałyby zatem ulec zmniejszeniu. Oznacza to również relatywne polepszenie sytuacji partii, które nie są objęte subwencjonowaniem z budżetu państwa.

Ostatni wyrok, który warto omówić datowany jest na 18 lipca 2012 r. (K 14/12). Związany jest on z odrzuceniem sprawozdania Komitetu Wyborczego PSL o przychodach, wydatkach i zobowiązaniach finansowych tego Komitetu w kontekście wyborów do Sejmu i do Senatu, przeprowadzonych 23 września $2001 \mathrm{r}^{17}$

16 Sąd konstytucyjny odwołał się przy tym do W. Sokolewicza, Uwagi do art. 11, w: Konstytucja Rzeczypospolitej Polskiej. Komentarz, t. 2, red. L. Garlicki, Warszawa 2007, s. 47-49 oraz M. Chmaja, Nowy system finansowania partii politycznych w Polsce, ,Przegląd Sejmowy” 2002, nr 2, s. 12-13.

${ }_{17}$ Szerzej na temat finansowania kampanii wyborczych P. Uziębło, Finansowanie kampanii 
W zakresie wybranych istotnych elementów merytorycznych należy przybliżyć stanowisko TK, zgodnie z którym niedopuszczalna jest kontrola konstytucyjna zaskarżonych przepisów ordynacji wyborczej. Przepisy te mają na celu zapewnienie jawności finansowania partii politycznych, zabezpieczenie równoprawnej konkurencji partii rywalizujących ze sobą w wyborach oraz zagwarantowanie, że pozyskiwane środki finansowe będą służyły rzeczywiście realizacji funkcji wyborczej partii oraz funkcji rządzenia, poprzez udział jej reprezentantów w strukturze władzy ustawodawczej, a niekiedy również we władzy wykonawczej. Trybunał podkreślił przy tym, że zakwestionowane przepisy ordynacji dotyczą sfery działalności partii politycznej, w której funkcjonuje ona jako ogniwo mechanizmu wyłaniania władz publicznych, element struktury i mechanizmu funkcjonowania systemu politycznego, a w konsekwencji także jako element struktury władz publicznych, realizując te funkcje w przeważającej części ze środków finansowych uzyskiwanych z budżetu państwa. Partia polityczna nie może w tym zakresie funkcjonować jako podmiot, któremu przysługuje konstytucyjna ochrona praw i wolności przed działalnością władzy publicznej, określona w rozdziale II Konstytucji RP. Stąd też TK umorzył postępowanie w zakresie kontroli konstytucyjnej zaskarżonych przepisów ordynacji uznając, że nie zachodzą przesłanki konieczności ochrony konstytucyjnych wolności i praw, ustalając zarazem, że zaskarżone przepisy ordynacji nie są już i nie mogą być stosowane po utracie powszechnej mocy obowiązywania przez ordynację.

$\mathrm{W}$ ramach podsumowania analizy orzecznictwa TK dotyczącego partii politycznych należy zauważyć głęboko zakorzenione podejście etatystyczne do tych podmiotów. Przede wszystkim prawodawca traktuje partie jako „przedłużenie” państwa, a z drugiej strony Trybunał konserwuje niejako takie podejście w ustalonej już linii orzeczniczej. Także partie polityczne i ich członkowie przejawiają inklinacje w kierunku sprawowania władzy, nie zaś rozwijania społeczeństwa obywatelskiego przez budowanie zrzeszeń obywateli posiadających wspólne poglądy polityczne i świadomie kształtujących własne państwo na zasadach dobrowolności i równości.

wyborczej w polskich wyborach parlamentarnych na mocy kodeksu wyborczego, w: Kodeks wyborczy. Wstępna ocena, red. K. Skotnicki, Warszawa 2011. 
Problematyka partii politycznych w orzecznictwie Trybunału Konstytucyjnego 41

\section{BIBLIOGRAFIA:}

Bartoszewicz M., Nadzór nad partiami politycznymi w polskim porzadku konstytucyjnym, Warszawa 2006.

Bidziński M., Finansowanie partii politycznych w Polsce, Warszawa 2011.

Bień-Kacała A., Finansowanie kampanii wyborczej partii politycznej ze środków pochodzacych z działalności gospodarczej, w: „Przemiany prawa wyborczego-doświadczenia nowych demokracji” Republika Czeska, Republika Słowacka, Republika Ukraińska, Rzeczpospolita Polska, red. A. Sokala, Z. Witkowski, Bydgoszcz 2007.

Bień-Kacała A., Ograniczenie finansowania partii politycznych z budżetu państwa a równowaga budżetowa $w$ dobie kryzysu (uwagi na tle wyroku TK z 20 stycznia 2010, Kp 6/09), w: Normalność i kryzys. Jedność czy różnorodność, red. J. Oniszczuk, Warszawa 2010.

Bożyk S., Partie polityczne a Sejm RP, Warszawa 2006.

Chmaj M., Nowy system finansowania partii politycznych w Polsce, „Przegląd Sejmowy” 2002, nr 2.

Chmaj M., Żmigrodzki M., Status prawny partii politycznych w Polsce, Toruń 1995

Domańska A., Skotnicki K (red.), Prawne aspekty funkcjonowania partii politycznych w państwach Europy Środkowej $i$ Wschodniej, Lódź 2003.

Kustra A., Trybunat Konstytucyjny, w: Prawo konstytucyjne, Z. Witkowski, A. Bień-Kacała (red.), Toruń 2015.

Majchrowski J., Partie polityczne w świetle nowej Konstytucji, „Państwo i Prawo” 1997, nr 11-12.

Serowaniec M., Likwidacja, podziat i łączenie partii politycznych $w$ Polsce, „Toruńskie studia polsko-włoskie/Studi polacco-italiani di Toruń” 2016, t. XII, DOI: http:// dx.doi.org/10.12775/TSP-W.2016.020.

Sokolewicz W., Uwagi do art. 11, w: Konstytucja Rzeczypospolitej Polskiej. Komentarz, t. 2, red. L. Garlicki, Warszawa 2007.

Sułkowski J., Pozycja ustrojowo prawna partii politycznych w Polsce, Czechach, na Słowacji i na Węgrzech, Lódź 2010.

Uliasz J., Władza sądownicza wobec partii politycznych w Polsce - zagadnienia wybrane, „Przegląd Prawa Konstytucyjnego“ 2011, nr 2.

Uziębło P., Finansowanie kampanii wyborczej w polskich wyborach parlamentarnych na mocy kodeksu wyborczego, w: Kodeks wyborczy. Wstępna ocena, red. K. Skotnicki, Warszawa 2011.

Zbieranek J. (red.), Subwencje z budżetu państwa dla partii politycznych. Jawność i kontrola, Warszawa 2008. 